\title{
Effect of nitrogen sources and 2, 4-D treatment on indirect regeneration of ginger (Zingiber officinale Rosc.) using leaf base explants
}

\author{
Valiyaparambath Musfir Mehaboob - Kunnampalli Faizal Palusamy Raja - Ganesan Thiagu Abubakker Aslam • \\ Appakan Shajahan
}

Received: 1 February 2019 / Revised: 2 March 2019 / Accepted: 2 March 2019

(c) Korean Society for Plant Biotechnology

\begin{abstract}
Ginger is an important monocotyledonous plant belonging to the family Zingiberaceae. The objective of this study was to investigate the regeneration potential of ginger using leaf base explants. Auxins such as 2, 4-D and NAA in combination with BA were used for initiation of callus. Different combinations of both ammonium $\left(\mathrm{NH}^{4+}\right)$ and nitrate $\left(\mathrm{NO}^{3-}\right)$ were also studied for efficient callus production. High frequency of white friable calli was observed on modified Murashige and Skoog (MS) medium supplemented with $2.0 \mathrm{mg} / \mathrm{L} 2$, 4-D, $0.5 \mathrm{mg} / \mathrm{L} \mathrm{NAA}$ and $0.5 \mathrm{mg} / \mathrm{L} \mathrm{BA}$. The highest shoot induction (92.33\%), shootlets number (7.33 \pm $0.33)$ and length $(88.33 \pm 4.40) \mathrm{mm}$ were achieved on MS media containing $0.5 \mathrm{mg} / \mathrm{L}$ BA. Regenerated shoots were transferred to in vitro rooting media containing $1.0 \mathrm{mg} / \mathrm{L}$ IBA. Afterwards, plantlets with well-developed root and shoot system were subjected to a twostep hardening process. $71 \%$ of plantlets survived after secondary hardening without any abnormal morphology.
\end{abstract}

Keywords Ginger, Callus, Ammonium, Nitrate, BA, Hardening

\section{Introduction}

Zingiber officinale Rosc., commonly known as ginger, is an essential spice crop of tropical south Asian countries and a common condiment for various foods and beverages as it gives taste and flavour. Gingerols, shagols, monoterpenes (geranial and neral) and sesquiterpenes ( $\beta$-bisabolene and zingiberene) are the major bioactive compounds present in

V. M. Mehaboob · K. Faizal · P. Raja · G. Thiagu • A. Aslam • A. Shajahan $(\varangle)$

Plant Molecular Biology Laboratory, Department of Botany, Jamal Mohamed College, Tiruchirappalli 620020, India e-mail: shajahan.jmc@gmail.com the ginger (Zuraida et al. 2016). These compounds have been used for their antioxidant, anti-inflammatory and cancer preventive properties (Shukla and Singh 2007).

Ginger is propagated vegetatively by underground rhizome at a low proliferation rate. The absence of natural seed set and lack of genetic variability have hampered the development of disease-resistant ginger by conventional breeding (Kackar et al. 1993). Hence, applying non-conventional method is necessary for the production and propagation of this important crop plant. Plant tissue culture techniques will help in the production of the improved disease-free cultivar with a rapid multiplication rate. Methods used for micropropagation of ginger include organ culture (Sharma and Singh 1997), protoplast culture (Geetha et al. 2000), somatic embryogenesis (Guo and Zhang 2005) and synthetic seed production (Nirmal Babu et al. 2016).

The chemical composition of culture media and optimization of mineral nutrients are very much important for the successful in vitro micropropogation. Nitrogen is an essential macronutrient for the synthesis of nucleic acids, proteins and secondary metabolites (Wada et al. 2015). In tissue culture, Optimum level of nitrogen is essential for callus production, shoot and root multiplication and embryogenesis (Shanjani 2003; Utsumi et al. 2017). Ammonium and nitrate are the two major sources of nitrogen in MS medium (Murashige and Skoog 1962). In our study, we tested the different levels of nitrogen and plant growth regulators for efficient callus production and propagation. There are several investigations on callus induction in ginger using shoot tip explants (Ibrahim et al. 2015; El-Nabarawy et al. 2015; Ali et al. 2016). Unlike shoot tips, leaf explants are easy to collect and need not to kill the mother plant and their availability is not limited to any seasons like inflorescence explant (Chugh et al. 2009). Nirmal Babu et al. (1992) reported the callus mediated regeneration of ginger using young leaves. But production of calli and the percentage 
of response were meager in these studies. The present study reveals the development of an efficient culture system from leaf base callus as well as transplantation of plantlets to natural field condition.

\section{Materials and Methods}

Plant material

The leaf base explants $(1 \sim 2 \mathrm{~cm})$ of $Z$. officinale plants were excised and disinfected with $2 \%(\mathrm{v} / \mathrm{v})$ Tween-20 for $5 \mathrm{~min}$ and $1 \%(\mathrm{w} / \mathrm{v})$ mercuric chloride $\left(\mathrm{HgCl}_{2}\right)$ for $2 \mathrm{~min}$, subsequently washed six times with sterilized distilled water, then transferred to MS medium supplemented with $3 \%(\mathrm{w} / \mathrm{v})$ sucrose and $0.8 \%(\mathrm{w} / \mathrm{v})$ agar. The $\mathrm{pH}$ of the medium was adjusted to $5.6 \sim 5.9$ before autoclaving at $121^{\circ} \mathrm{C}$ and $104 \mathrm{~K}$ pa pressure for $20 \mathrm{~min}$. The cultures were maintained in an air-conditioned room at $22 \pm 2^{\circ} \mathrm{C}$ with photoperiod of 16 $\mathrm{hr}$ light and $8 \mathrm{hr}$ dark with a light intensity of $40 \mu \mathrm{mol}$ $\mathrm{m}^{-2} \mathrm{~s}^{-1}$.

\section{Callus induction}

Leaf base explants were inoculated on MS solid medium with different plant growth regulators (PGRs) either alone or in combination to induce callus. Modified MS media were tested for the callus induction by using different levels of nitrogen sources ranges from 2280 to $973 \mathrm{mg} / \mathrm{L}$ $\mathrm{KNO}_{3}$ and 1650 to $845 \mathrm{mg} / \mathrm{L} \mathrm{NH}_{4} \mathrm{NO}_{3}$ (Table 1). Each experimental unit consisted of 12 tubes, and the explants were incubated under standard culture conditions. Calli were subcultured within an interval of 3 weeks. The calli formation frequency in different media were recorded.

Shoot organogenesis from callus culture

After leaf base was cultured for a total of $3 \sim 4$ weeks, proliferated calli were separated from leaf base explant and cut into pieces with a weight of approximately 100 $\mathrm{mg}$, then transferred to a petri dish containing MS medium with various concentrations of $\mathrm{BA}$ and $3 \%$ sucrose. The shoots and leaves elongated subsequently, so the number of calli forming shoots were recorded after 4 weeks of culture period and subcultured every 3 weeks for regeneration of plantlets. Regenerated shoots $(3 \sim 4 \mathrm{~cm})$ were transferred to MS medium containing IAA and IBA ( 0.5 to $1.5 \mathrm{mg} / \mathrm{L})$ for in vitro rooting

\section{Acclimatization}

Well grown plantlets were removed from the culture jars and washed under tap water to remove agar. Then the plantlets were transferred to small paper cups containing the autoclaved mixture of the vermiculite, soil and sand (1:2:1) and kept at temperature $28 \pm 2^{\circ} \mathrm{C}$ and $70 \sim 80 \%$ relative humidity. Randomly selected primary hardened plants were transferred to earthen pots containing cattle manure, soil and sand (1:2:1) for secondary hardening and acclimatization.

\section{Statistical analysis}

All experiments were repeated three times with at least 12 explants. All data were subjected to one way ANOVA with a statistical significance test.

\section{Results and Discussion}

\section{Callus induction}

The presence of auxin along with cytokinin is a potent hormonal combination for indirect shoot induction as reported by Skoog and Miller (1957). Sterilized young leaf base explants were cultured on MS medium supplemented with different combinations of 2,4-D, NAA, and BA. After $3 \sim 4$ weeks of culture, explants showed leaf folding, bulging and decolouration. Callus growth started from the surface of the leaf base explant, and the nature of calli were

Table 1 Composition of MS macronutrients used for callus formation in ginger

\begin{tabular}{lccccc}
\hline \multirow{2}{*}{ MS Macronutrients } & $\begin{array}{c}\text { Standard MS medium } \\
(\mathrm{mg} / \mathrm{L})\end{array}$ & MS1 & MS2 & MS3 & MS4 \\
\cline { 3 - 6 } & 1900 & 2280 & 1520 & 1216 & 973 \\
$\mathrm{KNO}_{3}$ & 1650 & 1980 & 1320 & 1056 & 845 \\
$\mathrm{NH}_{4} \mathrm{NO}_{3}$ & 440 & 440 & 440 & 440 & 440 \\
$\mathrm{CaCl}_{2} \cdot 2 \mathrm{H} 2_{\mathrm{O}}$ & 170 & 170 & 170 & 170 & 170 \\
$\mathrm{KH}_{2} \mathrm{PO}_{4}$ & 370 & 370 & 370 & 370 & 370 \\
$\mathrm{MgSO}_{4} \cdot 7 \mathrm{H} 2_{\mathrm{O}}$ & & & & \\
\hline
\end{tabular}


Table 2 Effect of growth regulators combination (2,4-D, BA and NAA) on the callus formation of ginger

\begin{tabular}{|c|c|c|c|c|c|c|c|}
\hline \multicolumn{4}{|c|}{ Plant growth regulators $(\mathrm{mg} / \mathrm{L})$} & \multicolumn{4}{|c|}{ Callus induction frequency (\%) in different nitrogen level } \\
\hline $2,4-\mathrm{D}$ & $\mathrm{BA}$ & NAA & $\begin{array}{l}\text { Standard MS } \\
\text { medium }\end{array}$ & MS1 & MS2 & MS3 & MS4 \\
\hline 0.0 & - & - & $0.0^{\mathrm{h}}$ & $0.0^{\mathrm{e}}$ & $0.0^{\mathrm{h}}$ & $0.0^{\mathrm{h}}$ & $0.0^{\mathrm{h}}$ \\
\hline 1.0 & - & - & $15.66 \pm 1.45^{\mathrm{g}}$ & $8.66 \pm 1.76^{\mathrm{d}}$ & $17.66 \pm 4.40^{\mathrm{g}}$ & $21.0 \pm 2.51^{\mathrm{g}}$ & $14.66 \pm 2.60^{\mathrm{g}}$ \\
\hline 1.5 & - & - & $18.33 \pm 1.20^{\mathrm{fg}}$ & $9.66 \pm 0.66^{\mathrm{d}}$ & $23.0 \pm 1.0^{\mathrm{g}}$ & $32.33 \pm 2.33^{\mathrm{f}}$ & $25.0 \pm 2.30^{\mathrm{f}}$ \\
\hline 2.0 & - & - & $25.0 \pm 1.73^{\mathrm{de}}$ & $18.0 \pm 1.52^{\mathrm{c}}$ & $35.33 \pm 2.33^{\mathrm{ef}}$ & $42.33 \pm 2.96^{\mathrm{e}}$ & $42.66 \pm 3.17^{\mathrm{d}}$ \\
\hline 2.5 & - & - & $21.0 \pm 2.64^{\mathrm{efg}}$ & $15.66 \pm 1.76^{\mathrm{c}}$ & $32.33 \pm 1.76^{\mathrm{f}}$ & $34.33 \pm 2.33^{\mathrm{f}}$ & $33.66 \pm 1.85^{\mathrm{e}}$ \\
\hline 2.0 & 0.3 & - & $27.33 \pm 2.18^{\mathrm{de}}$ & $17.66 \pm 1.85^{\mathrm{c}}$ & $42.0 \pm 3.78^{\mathrm{de}}$ & $51.66 \pm 1.76^{\mathrm{d}}$ & $41.0 \pm 4.35^{\mathrm{de}}$ \\
\hline 2.0 & 0.5 & - & $29.66 \pm 0.66^{\mathrm{d}}$ & $20.0 \pm 0.57^{\mathrm{c}}$ & $49.66 \pm 1.20^{\mathrm{cd}}$ & $81.66 \pm 2.02^{\mathrm{b}}$ & $51.66 \pm 2.18^{\mathrm{c}}$ \\
\hline 2.0 & 1.0 & - & $24.33 \pm 2.02^{\text {def }}$ & $17.66 \pm 1.45^{\mathrm{c}}$ & $48.0 \pm 2.30^{\mathrm{d}}$ & $66.66 \pm 4.63^{c}$ & $57.33 \pm 3.17^{\mathrm{c}}$ \\
\hline 2.0 & 0.5 & 0.3 & $42.0 \pm 1.52^{\mathrm{c}}$ & $26.33 \pm 2.18^{b}$ & $56.66 \pm 1.20^{\mathrm{bc}}$ & $81.66 \pm 2.3^{\mathrm{b}}$ & $66.33 \pm 2.02^{\mathrm{b}}$ \\
\hline 2.0 & 0.5 & 0.5 & $57.33 \pm 4.09^{\mathrm{a}}$ & $31.33 \pm 1.20^{\mathrm{a}}$ & $69.0 \pm 1.52^{\mathrm{a}}$ & $92.0 \pm 2.08^{\mathrm{a}}$ & $76.0 \pm 2.88^{\mathrm{a}}$ \\
\hline 2.0 & 0.5 & 1.0 & $50.66 \pm 2.02^{\mathrm{b}}$ & $29.66 \pm 2.02^{\mathrm{ab}}$ & $63.33 \pm 4.25^{\mathrm{ab}}$ & $75.0 \pm 2.30^{\mathrm{b}}$ & $70.0 \pm 2.64^{\mathrm{ab}}$ \\
\hline
\end{tabular}

Values are expressed as the mean $\pm \mathrm{SE}$, taking ten explants in each experiment with three replications. Within each group, values with different letters indicate significant difference at $P \geq 0.05$ using Duncan's multiple range test (DMRT)

Table 3 Effect of BA on shoot regeneration from in vitro grown callus of ginger

\begin{tabular}{cccc}
\hline $\begin{array}{c}\text { BA } \\
(\mathrm{mg} / \mathrm{L})\end{array}$ & $\begin{array}{c}\text { Shoot induction } \\
(\%)\end{array}$ & $\begin{array}{c}\text { Mean number of } \\
\text { shoots/callus }\end{array}$ & $\begin{array}{c}\text { Mean plantlet length } \\
(\mathrm{mm})\end{array}$ \\
\hline 0.0 & $16.0 \pm 2.88^{\mathrm{d}}$ & $2.0 \pm 0.57^{\mathrm{c}}$ & $51.66 \pm 1.66^{\mathrm{c}}$ \\
0.25 & $67.0 \pm 3.05^{\mathrm{c}}$ & $5.33 \pm 0.88^{\mathrm{b}}$ & $68.33 \pm 4.40^{\mathrm{b}}$ \\
0.5 & $92.33 \pm 2.02^{\mathrm{a}}$ & $7.33 \pm 0.33^{\mathrm{a}}$ & $88.33 \pm 4.40^{\mathrm{a}}$ \\
0.75 & $78.66 \pm 3.17^{\mathrm{b}}$ & $5.66 \pm 0.33^{\mathrm{ab}}$ & $78.33 \pm 3.33^{\mathrm{ab}}$ \\
1.0 & $72.33 \pm 1.15^{\mathrm{bc}}$ & $5.0 \pm 0.57^{\mathrm{b}}$ & $75.0 \pm 2.88^{\mathrm{b}}$ \\
\hline
\end{tabular}

Values are expressed as the mean \pm SE, taking ten explants in each experiment with three replications. Within each group, values with different letters indicate significant difference at $P \geq 0.05$ using Duncan's multiple range test (DMRT)

varied from compact to friable and brownish to white in the reduced nitrogen medium. Maximum number of friable white calli were observed in MS Macronutrients containing $1216 \mathrm{mg} / \mathrm{L} \mathrm{KNO}_{3}$ and $1056 \mathrm{mg} / \mathrm{L} \mathrm{NH}_{4} \mathrm{NO}_{3}$ (Table 1). The effect of nitrogen on callus production is studied on different plants like Sorghum (Elkonin et al. 2000), Wheat (He et al. 1989) and Cassava (Utsumi et al. 2017). MS3 (Table 1) medium containing $2.0 \mathrm{mg} / \mathrm{L}$ 2,4-D in combination with $0.5 \mathrm{mg} / \mathrm{L} \mathrm{NAA}$ found to be the best for maximum callus induction (92\%) (Table 2). Earlier reports also revealed that MS medium supplemented with 2,4-D is the optimum condition for the callus induction in ginger (Ibrahim et al. 2015; El-Nabarawy et al. 2015). The effect of 2,4-D for inducing callus might be due to their role in DNA replication and mitosis (Sen et al. 2014).

Effect of BA on shoot induction

Well-developed white compact calli obtained from leaf sheath explants were transferred to auxin-free MS medium containing BA alone. The presence of BA is necessary for indirect organogenesis in ginger and the maximum number of shoots (7.33 \pm 0.33$)$ induced on MS medium supplemented with $0.5 \mathrm{mg} / \mathrm{L}$ BA. High frequency $(92.33 \%)$ of shoot induction was recorded in this concentration (Table 3). Similar results were also reported in Alpinia calcarata (Bhowmik et al. 2016).

\section{Effect of auxins on in vitro rooting}

In the present study, the addition of IAA and IBA to the culture medium enhanced the root induction and elongation. Among the auxins supplemented for in vitro rooting, the best result noted on $1.0 \mathrm{mg} / \mathrm{L}$ IBA with $97.66 \%$ rooting response (Table 4). These observations are in accordance with the result obtained in Coleus blumei (Rani et al. 2006), Solanum nigrum (Sridhar and Naidu 2011) and Curcuma amada (Raju et al. 2015).

Acclimatization

The rooted plantlets were transferred to paper cups containing 
Table 4 Effect of auxins (IAA and IBA) on root induction from in vitro regenerated shoots of ginger

\begin{tabular}{|c|c|c|c|c|}
\hline \multicolumn{2}{|c|}{ Plant growth regulators $(\mathrm{mg} / \mathrm{L})$} & \multirow{2}{*}{ Days for root induction } & \multirow{2}{*}{ Rooting (\%) } & \multirow{2}{*}{ Number of roots per explant } \\
\hline IAA & IBA & & & \\
\hline 0.0 & 0.0 & $15-20$ & $22.0 \pm 2.08^{\mathrm{g}}$ & $4.33 \pm 0.66^{\mathrm{e}}$ \\
\hline 0.5 & - & $16-18$ & $44.0 \pm 1.52^{\mathrm{f}}$ & $8.33 \pm 0.33^{\mathrm{d}}$ \\
\hline 1.0 & - & $15-17$ & $60.0 \pm 3.21^{\mathrm{d}}$ & $11.33 \pm 0.88^{\mathrm{c}}$ \\
\hline 1.5 & - & $16-18$ & $53.33 \pm 1.85^{\mathrm{e}}$ & $12.66 \pm 0.88^{\mathrm{c}}$ \\
\hline- & 0.5 & $10-12$ & $69.66 \pm 2.90^{\mathrm{c}}$ & $16.33 \pm 0.88^{b}$ \\
\hline- & 1.0 & $10-12$ & $97.66 \pm 0.33^{\mathrm{a}}$ & $22.66 \pm 0.88^{\mathrm{a}}$ \\
\hline- & 1.5 & $13-15$ & $83.0 \pm 2.08^{\mathrm{b}}$ & $18.33 \pm 0.57^{\mathrm{b}}$ \\
\hline
\end{tabular}

Values are expressed as the mean $\pm \mathrm{SE}$, taking ten explants in each experiment with three replications. Within each group, values with different letters indicate significant difference at $P \geq 0.05$ using Duncan's multiple range test (DMRT)

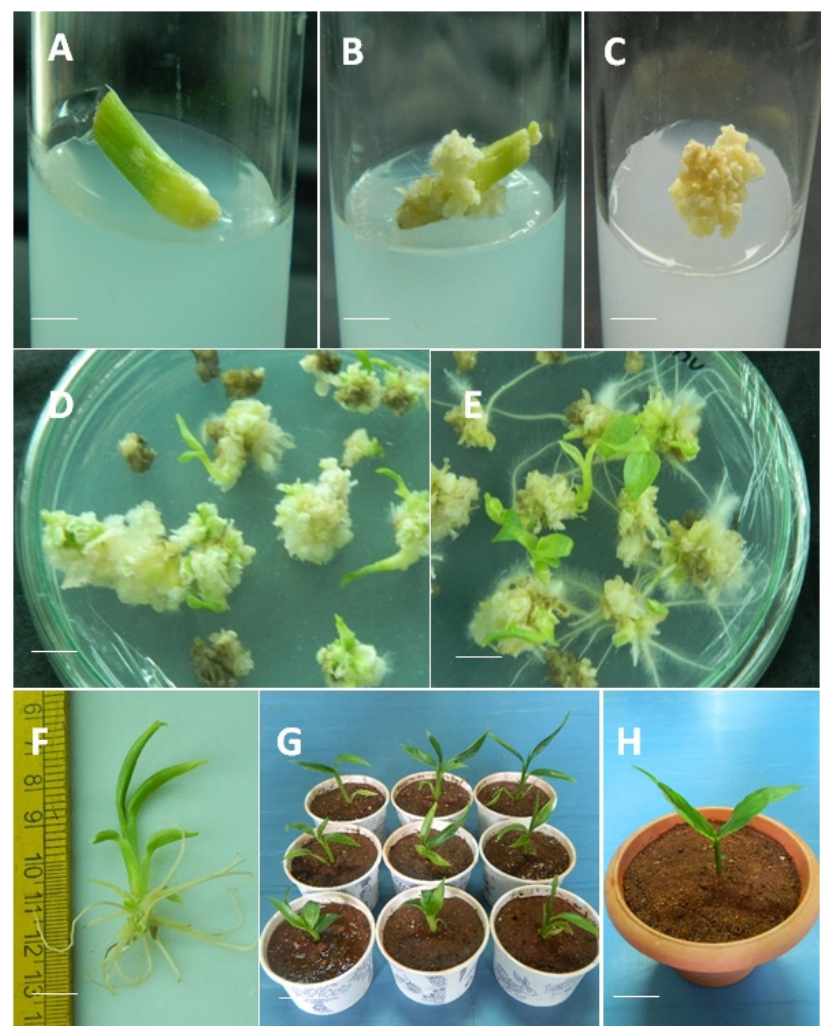

Fig. 1 Callus induction and plantlet regeneration in ginger. (A) Sterilized leaf base explant. (B) White compact calli on the surface of leaf base explant. (C) Friable calli on MS3 medium. (D) Indirect organogenesis on shoot induction medium. (E) Root development in rooting medium. (F) Plantlets excised for hardening. (G) One month old primary hardened plant. (H) 2 month old secondary hardened plant. Bars: (A-C) $0.5 \mathrm{~cm}$; (D-F) $1 \mathrm{~cm} ;(\mathrm{G} \& \mathrm{H}) 3 \mathrm{~cm}$

a mixture of vermiculite, soil and sand (1:2:1) (Fig. 1G). After 3 4 weeks of primary hardening, $83 \%$ of plants survived and transferred for secondary hardening in earthen pots (Fig. 1H). It was noted that the survival rate was decreased to $71 \%$ under the shade house. The regenerates did not show any morphological variations, but genetic variations is yet to be investigated.

\section{Conclusion}

We have developed an indirect plant regeneration protocol through leaf base explant for ginger, an important spice crop using worldwide. This method is simple, highly reproducible and yields a large number of acclimatized plants. This study indicates that leaf base explants are efficient in terms of indirect organogenesis and shoot multiplication. Production of friable calli by 2,4-D treatment and reduced nitrogen level are the highlights of this study. This protocol will provide a basis for rapid large scale production of ginger in a considerably short period and also useful for the future applications in ginger transformation studies.

\section{Reference}

Ali AMA, El-Nour, MEM, Yagi SM (2016) Callus induction, direct and indirect organogenesis of ginger (Zingiber officinale Rosc). Afr J Biotechnol 15(38):2106-2114

Bhowmik SSD, Basu A, Sahoo L (2016) Direct shoot organogenesis from rhizomes of medicinal Zingiber Alpinia calcarata Rosc. and evaluation of genetic stability by RAPD and ISSR markers. J Crop Sci Biotech 19(2):157-165

Chugh S, Guha S, Usha RI (2009) Micropropagation of orchids: a review on the potential of different explants. Sci Hortic 122:507-520

Elkonin LA, Pakhomova NV (2000) Influence of nitrogen and phosphorus on induction of embryogenic callus of sorghum. Plant Cell Tiss Org Cult 61:115-123

El-Nabarawy MA, El-Kafafi SH, Hamza MA, Omar MA (2015) The effect of some factors on stimulating the growth and production of active substances in Zingiber officinale callus cultures. Ann Agric Sci 60:1-9 
Geetha SP, Babu KN, Rema J (2000) Isolation of protoplasts from cardamom (Elettaria cardamomum Maton.) and ginger (Zingiber officinale Rosc.). J Spices Aromatic Crops 9(1):23-30

Guo YH, Zhang ZX (2005) Establishment and plant regeneration of somatic embryogenic cell suspension cultures of the Zingiber officinale Rosc. Sci Hortic 107:90-96

He DG, Yang YM, Scott KJ (1989) The effect of macroelements in the induction of embryogenic callus from immature embryos of wheat (Triticum aestivum L.). Plant Sci 64:251-258

Ibrahim DA, Danial GH, Mosa VM, Khalil BM (2015) Plant regeneration from shoot tips-derived callus of ginger (Zingiber officinale Rosc.). Am J Exp Agric 7(1):55-61

Kacker A, Bhat SR, Chandel KPS, Malik SK (1993) Plant regeneration via somatic embryogenesis in ginger. Plant Cell Tiss Org Cult. 32:289-292

Murashige T, Skoog F (1962) A revised medium for rapid growth and bioassays with tobacco tissue cultures. Physiol Plant. 15:473-497

Nirmal Babu K, Samsudeen K, Divakaran M, Pillai GS, Sumathi, V, Praveen K, Ravindran PN, Peter KV (2016) Protocols for in vitro Propagation, Conservation, Synthetic Seed Production, Embryo Rescue, Microrhizome Production, Molecular Profiling and Genetic Transformation in Ginger (Zingiber officinale Roscoe.). Protocols for in vitro Cultures and Secondary Metabolite Analysis of Aromatic and Medicinal Plants, Second Edition, pp 403-426

Nirmal Babu K, Samsudeen K, Ratnambal MJ (1992) In vitro plant regeneration from leaf-derived callus in ginger (Zingiber officinale Rosc.). Plant Cell Tissue Org Cult 29:71-74

Raju SR, Varutharaju K, Thilip C, Aslam A, Shajahan A (2015) Rhizogenesis in cell suspension culture from Mango Ginger: A Source of Isosorbide and n-Hexadecanoic Acid. Advances in Botany. 7 pp

Rani G, Talwar D, Nagpal A, Virk, GS (2006) Micropropagation of Coleus blumei from nodal segments and shoot tips. Biol Plant 50:496-500

Sen MK, Nasrin S, Rahman S, Jamal AHM (2014) In vitro callus induction and plantlet regeneration of Achyranthes aspera L., a high value medicinal plant. Asian Pac J Trop Biomed 4(1):40-46

Shanjani PS (2003) Nitrogen effect on callus induction and plant regeneration of Juniperus excelsa. Int J agr Biol 5:419-422

Sharma TR, Singh BM (1997) High frequency in vitro multiplication of disease-free Zingiber officinale Rosc. Plant Cell Rep 17:68-72

Shukla Y, Singh M (2007) Cancer preventive properties of ginger: a brief review. Food Chem Toxicol 45:683-690

Skoog F, Miller CO (1957) Chemical regulation of growth and organ formation in plant tissues cultured in vitro. Symp Soc Exp Biol 11:118-131

Sridhar TM, Naidu CV (2011) An efficient callus induction and plant regeneration of Solanum nigrum (L.) an important antiulcer medicinal plant. J Phytol 3(5):23-28

Utsumi Y, Utsumi C, Tanaka M, Ha VT, Matsui A, Takahashi S, Seki M (2017) Formation of friable embryogenic callus in cassava is enhanced under conditions of reduced nitrate, potassium and phosphate. PLoS ONE 12(8): e0180736

Wada S, Niedz RP, Reed B (2015) Determining nitrate and ammonium requirements for optimal in vitro response of diverse pear species. In Vitro Cell Dev Biol Plant 51:19-27

Zuraida AR, Mohd Shukri MA, Erny SMN, Ayu N, Che Radziah CZ, Pavallekoodi G, Sreeramanan S (2016) Micropropagation of ginger (Zingiber officinale var. Rubrum) using buds from microshoots. Pak J Bot 48(3):1153-1158 